\title{
A new look at evolution in the Galapagos: evidence from the late Genozoic marine molluscan fauna
}

\author{
M. J. JAMES \\ Department of Paleontology, University of California, \\ Berkeley, California 94720, U.S.A.
}

\begin{abstract}
Endemism is not as common in the marine invertebrate fauna of the Galapagos Islands region as in the adjacent terrestrial biota. Marine invertebrates in the Galapagos are largely cosmopolitan species from the Panamic, Indo-Pacific, Californian, or Peruvian faunal provinces. However, an endemic component is also present in the fauna. The observed pattern among marine invertebrate organisms can be accounted for by at least two processes: (1) genetic continuity between mainland and island populations mediated through planktonic larvae; and (2) lower rates of intrinsic evolutionary change. The evolutionary scenario standardly applied to terrestrial organisms in the Galapagos, namely, adaptive radiation and speciation in reproductive isolation from mainland source populations, does not apply to all marine invertebrates. Evidence in support of the alternative scenario for marine invertebrates comes from both published records of species occurring in the islands and recent studies of fossil-bearing deposits on several islands in the archipelago. Two misconceptions considering the islands and sedimentary deposits to be older than now thought, and equating the rate of evolution of the terrestrial biota with the marine biota - can lead to an incorrect interpretation of evolution in the Galapagos. Contrasts between marine invertebrate and terrestrial organisms serve to illustrate some fundamental differences which have important evolutionary implications. Some of these are: endemism; dispersal; taxonomic relationships; island definitions; rates of evolutionary change; and age of fossils. In terms of Darwin's evolutionary scenario, terrestrial organisms represent the paradigm and marine organisms represent the paradox.
\end{abstract}




\section{INTRODUCTION}

The Galapagos Islands have been of great interest to evolutionary biologists for many years. This is primarily due to the unique terrestrial biota that stands as a paradigm to the work of Charles Darwin. Adaptive radiation and speciation in reproductive isolation from mainland source populations are the processes invoked to account for the pattern of endemic insular taxa. Unfortunately, the marine invertebrate fauna has not received as much attention as the well-known terrestrial biota (Hedgpeth, 1969). The purpose of this paper is to review what is known about evolution of marine invertebrates (particularly molluscs) in the Galapagos, using examples from Neogene and Recent taxa. Investigation of evolutionary rates and patterns among Galapagos organisms will result in an understanding of evolutionary mechanisms among the studied species.

In February 1982, I participated in a palaeontological expedition to the Galapagos Islands in which the primary goal was to collect both palaeontological and stratigraphic information. Previous research expeditions to the islands have collected fossils either incidentally or as a secondary objective, usually while studying a neontological topic. A systematic and thorough field sampling programme was undertaken (see Fig. 1 for all island localities mentioned in text). The main objective was to gain an improved understanding of the taxonomy, stratigraphy, palaeoecology, palaeobiogeography, and evolutionary implications of previously-reported Late Cenozoic fossil faunas of the Galapagos.

Also participating in the 1982 expedition were William D. Pitt (trip organizer, Sacramento, California) and Lois J. Pitt; Carole S. Hickman (University of California, Berkeley); and Jere H. Lipps (University of California, Davis). The results of this expedition (which represent the combined efforts of all five participants) and additional information assembled from the literature by this author have shed new light on the taxonomic, biogeographic, and evolutionary relationships of the Late Cenozoic marine invertebrate fauna of the Galapagos Islands.

\section{GEOGRAPHIC SETTING}

The Galapagos Islands are true oceanic islands situated astride the equator spread over a wide geographic area ranging from longitude $89^{\circ} 15^{\prime} 30^{\prime \prime} \mathrm{W}$ to $92^{\circ}$ 
$01^{\prime} 00^{\prime \prime} \mathrm{W}$ and from latitude $1^{\circ} 40^{\prime} 00^{\prime \prime} \mathrm{N}$ to $1^{\circ} 36^{\prime} 00^{\prime \prime} \mathrm{S}$ (Fig. 1). Geographically, these islands are not a compact, coherent group, as they extend both above and below the equator, and are influenced by different oceanographic conditions in the north and south (Abbott, 1966; Wooster and Hedgpeth, 1966). However, the Galapagos are by no means the most isolated island group in the world, being surpassed in this regard by the Hawaiian Islands.

\section{BIOGEOGRAPHIC SETTING}

The marine invertebrate biota (particularly the molluscs) of the Galapagos consists of three distinct components: (1) a tropical eastern Pacific element consisting of species from the Panamic faunal province (Keen, 1971); (2) true

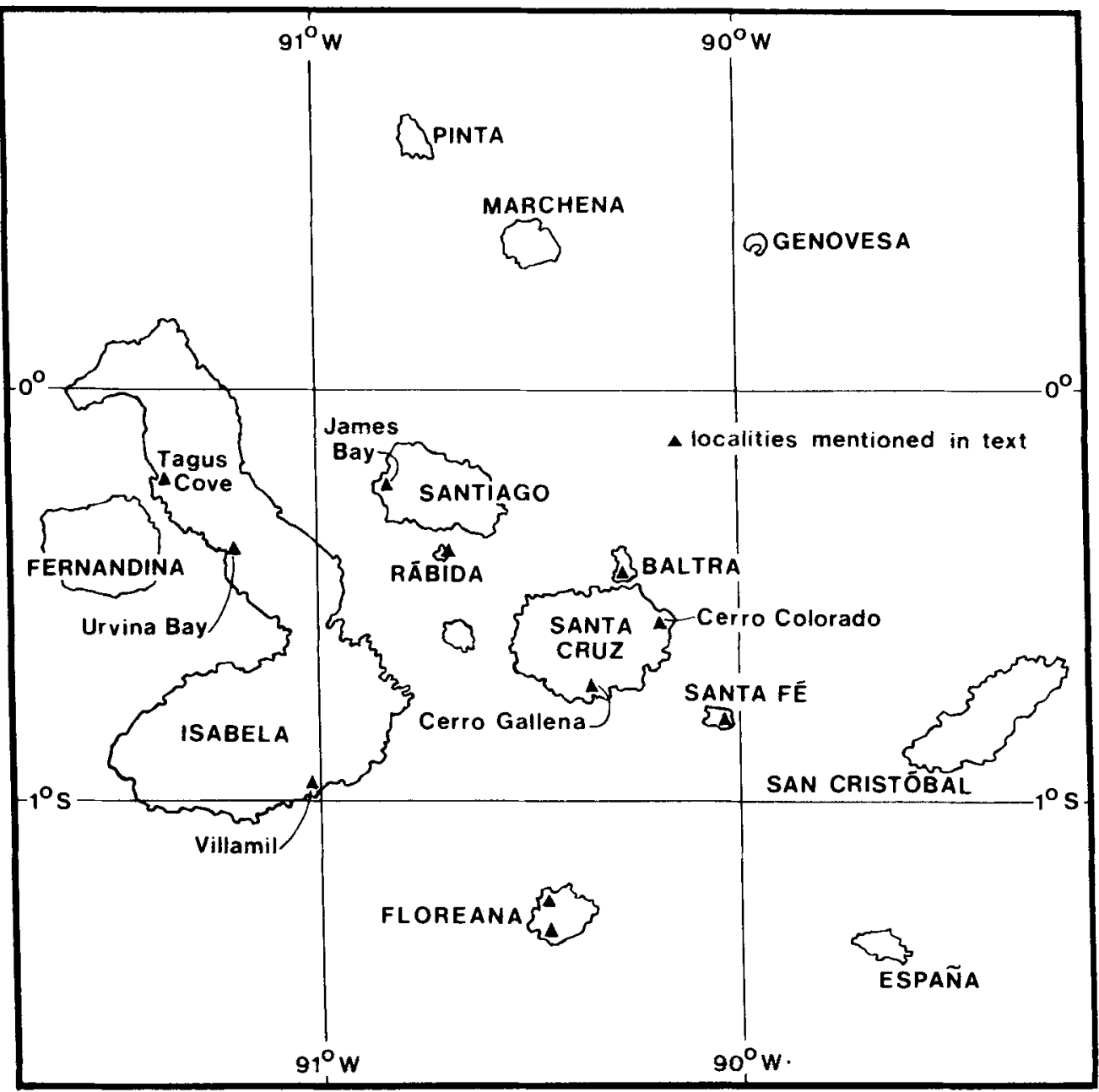

Figure 1. Late Cenozoic marine invertebrate localities in the Galapagos Islands (A). Co-ordinates of fossil locality on San Gristobal metioned by Charles Darwin (see text for discussion) are unknown. 
endemic shallow-water species that are unique to the islands, only a few of which are higher taxa (Keen, 1971), and (3) vagrant species from the IndoPacific, Californian, and Peruvian faunal provinces (Emerson, 1967, 1978; Marincovich, 1973; Lindberg \& McLean, 1981). Species in the first component occur in both the Galapagos and mainland populations. The second component consists of valid species, based on neontological or palaeontological definitions, that are either extant or extinct in the islands today. These taxa arrived in the islands, diverged sufficiently to be considered valid species and, by definition, do not occur elsewhere in the world. Populations of the third component have become established on the islands through dispersal mechanisms, such as oceanic current transport. A fourth, and as yet unrecognized, faunal element appears to be a deep-water highly endemic species group (J. W. Valentine, pers. comm., 29 January 1983; currently under investigation by J. W. Valentine \& D. Jablonski). Deep-water (i.e. bathyal and abyssal) highly endemic gastropod faunas are not unknown or unusual. Hickman (1976) has documented a fauna of bathyal gastropods of the family Turridae from Oligocene deposits in Oregon.

Although unlikely, biogeographic affinities between the Galapagos fossil fauna and species in the Caribbean faunal province cannot be ruled out completely. Keigwin (1978) has stated that the Panama Land Bridge closed at 3.1 My B.P., effectively preventing marine faunal interchange between the two areas after that time. Cox (1983) and Simkin (in press) have summarized information about ages of the Galapagos, and Hall, Ramon \& Yepes (1980) have presented evidence suggesting that subaerial islands existed in the Galapagos Archipelago at least 3.3 My ago. The difference of about $0.2 \mathrm{My}$ (or 200000 years) would be the 'window' during which deposits (as yet undiscovered) in the Galapagos could potentially contain taxa with direct affinities to the Caribbean faunal province. However, Geister (1977) has presented evidence that several seaways existed between the eastern Pacific and Caribbean during late Pleistocene interglacial high sea-level stands. Using occurrences of the reef coral Pocillopora in late Pleistocene Caribbean deposits, Geister presented arguments for either survival of Pocillopora from the Tertiary Caribbean coral fauna or a hypothetical re-introduction from the eastern Pacific. Durham (1980) considered the appearance of Pocillopora in Pleistocene deposits on Guadalupe Island, Mexico (eastern Pacific), to be synchronous with some of the Caribbean occurrences. Vermeij (1978: 258-266) has reviewed problems of the direction and magnitude of biotic interchange between the eastern Pacific and Caribbean if a sea-level connection occurred. If the Pleistocene openings of the Isthmus of Panama were of sufficient duration, then biotic contact between the Caribbean and eastern Pacific (and thus Galapagos) could have occurred intermittently.

An interesting pattern has emerged from the study of Indo-Pacific faunal elements occurring in the eastern Pacific (Emerson, 1967, 1978). Occasional Indo-Pacific vagrant species occur on true oceanic islands in the eastern Pacific. However, very few species successfully transverse the relatively short distance to the tropical American mainland and, to date, no Panamic species are known to have undergone the reverse pattern of establishing populations in the IndoPacific faunal province (Emerson, 1967). This pattern of unequal interchange between the two provinces is not adequately explained by the lack of 
distributing mechanisms from the Panamic province to the Indo-Pacific province (Abbott, 1966).

Factors influencing the biogeographic affinities of the Galapagos marine invertebrate fauna have been summarized by Abbott (1966). These are: (1) distributing mechanisms and access routes; (2) physical barriers; (3) temperature controls on colonization; and (4) incidence of pelagic larvae and timing of reproductive cycles. Distributing mechanisms and access routes consist of ocean currents that carry planktonic larvae to and from the islands. To a lesser degree, adult marine invertebrates can also be transported on drifting debris. A more remote possibility is transport to the islands as part of the fouling community on ship bottoms. Physical barriers to distribution consist of the Panama Land Bridge and Ekman's East Pacific Barrier (Ekman, 1953: 72-77), both of which obstruct east-west exchanges, and various ocean currents that obstruct north-south exchanges. Temperature regimes in inshore waters around the islands control the successful colonization by species of particular temperature tolerances. The incidence of pelagic larvae and the timing of reproductive cycles affect the 'raw material' available for oceanic current dispersal.

In terms of numbers of species, the Galapagos invertebrate fauna is depauperate (Table 1) with respect to the Panamic faunal province (Emerson, 1967). Kay (1979: 14) comments on the similarly depauperate or attenuate nature of the Hawaiian mollusc fauna in comparison to the Indo-Pacific faunal province. Several physical factors may explain the reduced species diversity of the Galapagos: (1) the islands are relatively isolated $(925 \mathrm{~km}$ west of Cabo San Lorenzo, Ecuador) from mainland source populations; (2) during part of the year oceanographic circulation brings cold water from the Humbolt (Peru Coastal) and the Peru Oceanic Currents to the islands (Abbott, 1966), which can operate as a selection mechanism preventing the establishment of stenothermic species; and (3) ocean currents in the eastern Pacific responsible for transporting planktonic larvae to the islands can be weak, indirect, or inconsistent. El Nino events (Wyrtki, Stroup, Patzert, Williams, \& Quinn, 1976), i.e., the appearance of warm, low salinity water in the eastern Pacific, increase growth rates of some coral species in the Galapagos (Druffel, 1981). The absence of true coral reef environments in the Galapagos and the Panamic province in general, accounts in part for the depauperate nature of the fauna (Emerson, 1967). However, substantial localized coral growth does occur in the Galapagos (Wellington, 1978; Glynn, Wellington, \& Birkeland, 1979). The implications of the geological nature of the islands for the shallow marine fauna and reef development have been investigated by Rosen (in prep.). A factor that does not limit the development of species populations in the islands is their geologic age, now considered to be Pliocene or Pleistocene based on K-Ar dating techniques (Cox, 1983, Simkin, in press). Both the probabilities of successful transport (dispersal) and successful population establishment (colonization) must be considered when evaluating the taxonomic and biogeographic affinities of species in the Galapagos.

An Atlantic Ocean analog to the Galapagos Islands may be St Paul's Rocks, an isolated group of barren islets lying on the mid-Atlantic ridge just north of the equator (Edwards \& Lubbock, 1983). However, important differences exist, particularly concerning the degrees of endemicity seen in the two areas. In 
the case of Galapagos molluscs, about $42 \%$ of the species are endemic (Table 1), but at St Paul's Rocks only 5\% of the shallow water marine fauna is endemic (four species of fishes) (Edwards \& Lubbock, 1983). Many biotic differences observed between the Galapagos and St Paul's Rocks are accounted for by components of MacArthur \& Wilson's (1967) theory of island biogeography, such as isolation, source areas, and area-diversity patterns. Williamson (1981: 82-92, 1983) has presented a critique of MacArthur \& Wilson (1967) pointing out that the "popular but obsolete" (Williamson, 1983) theory is being replaced as new theories are developed. Berry (1979) has suggested a cautious approach to the application of island biogeography theory, preferring instead a species-byspecies analysis to more accurately determine causal mechanisms.

\section{THE GALAPAGOS MALACOFAUNA}

Table 1 presents a compilation of information taken mainly from Keen (1971) on the occurrence of molluscs in the Panamic province and the Galapagos. This is only a first approximation of the malacofauna of the islands and should be interpreted as such. Much additional information must be gathered from field studies and the literature before complete knowledge of Galapagos molluscs is possible. When additional distributional data becomes available, the exact values in Table 1 will change but the general pattern will likely remain.

Two conclusions can be made from the data in Table 1. First, the Galapagos islands contain only a small percentage $(12 \%)$ of the molluscan species found in the Panamic province (323 of 2803 species, or 12\%). For those taxonomic groups that occur in the Galapagos (i.e. excluding Aplacophora and Monoplacophora), only between $6 \%$ and $31 \%$ of the known Panamic species are found in the islands. Thus, the Galapagos can be considered a depauperate outpost of the Panamic province. Second, overall species endemism is moderately high (mean 42\%) using the criteria of Briggs (1966). If one considers only the prosobranch gastropods (taxonomically the most intensely studied group of molluscs), then the degree of species endemism is higher $(45 \%)$. However, the pattern of molluscan endemism established here does not conform to the predictions of Briggs (1966) concerning degrees of endemism in relation to changes in marine palaeotemperatures during the Pleistocene glaciations. Lindberg, Roth, Kellogg \& Hubbs (1980) consider the distance of an island (or island group) from the mainland as an ameliorating factor in the influence of Pleistocene glaciations on marine palaeotemperatures. Given these conditions, high endemism will be predicted, contrary to Briggs (1966), for the Galapagos. Other groups of Galapagos marine organisms exhibit lower endemism (shore fishes $27 \%$ (Walker \& Rosenblatt, 1961) and brachyuran crabs 15\% (Garth, 1946)) and conform to the predictions of Briggs (1966).

For the molluscan groups presented in Table 1 that occur in the islands, endemism ranges from 0\% (Scaphopoda) to 75\% (Cephalopoda). The classes Aplacophora and Monoplacophora are apparently unknown from the Galapagos according to Keen (1971). Only $6 \%$ of the Panamic Bivalvia occur in the Galapagos. This low figure is not completely explained by the dispersal abilities of bivalves (see Jablonski \& Lutz, 1983). Perhaps it is because bivalves have been overlooked by collectors in the area. The Scaphopoda are not represented by endemic species in the Galapagos. 


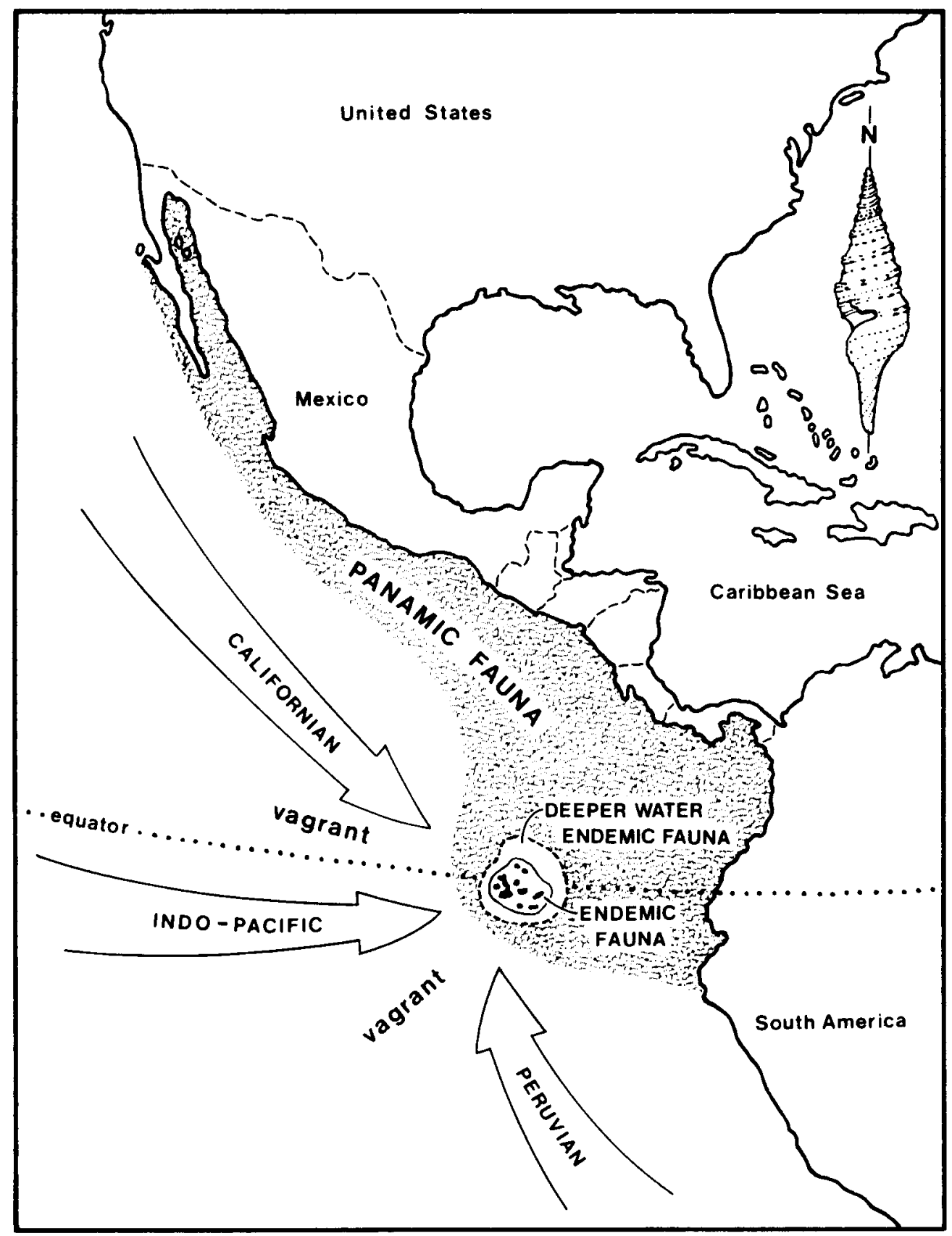

Figure 2. Biogeographic source elements for the Galapagos Islands marine invertebrate fauna, relying particularly on molluscan distributional data. Large arrows indicate faunal elements dispersed to the Galapagos from the Indo-Pacific, Peruvian, and Californian faunal provinces. The bulk of the Galapagos marine biota originates in the Panamic province. Near-shore and deeper water endemic faunas are Panamic subsets. 
Table 1. Composition of the Galapagos Islands malacofauna. Data from Keen (1971), with additional information from Lindberg \& McLean (1981), Smith \& Ferreia (1977), and Ferreia (1978)

\begin{tabular}{|c|c|c|c|c|c|}
\hline Taxonomic group & $\begin{array}{c}\text { No. of } \\
\text { Panamic } \\
\text { spp.* }\end{array}$ & $\begin{array}{c}\text { No. of } \\
\text { Galapagos } \\
\text { spp. }{ }^{\circ}\end{array}$ & $\begin{array}{l}\text { Percentage } \\
\text { Panamic in } \\
\text { Galapagos }+\end{array}$ & $\begin{array}{c}\text { No. of } \\
\text { Galapagos } \\
\text { endemics§ }\end{array}$ & $\begin{array}{l}\text { Percentage } \\
\text { endemic }\end{array}$ \\
\hline \multicolumn{6}{|l|}{ Prosobranchia } \\
\hline Archeogastropoda & 182 & 37 & 20 & 20 & 54 \\
\hline Mesogastropoda & 797 & 88 & 11 & 34 & 39 \\
\hline Neogastropoda & 893 & 127 & 14 & 59 & 47 \\
\hline Bivalvia & 803 & 44 & 6 & 10 & 23 \\
\hline Polyplacophora & 54 & 12 & 22 & 8 & 67 \\
\hline Scaphopoda & 25 & 5 & 20 & 0 & - \\
\hline Cephalopoda & 13 & 4 & 31 & 3 & 75 \\
\hline Aplacophora & 1 & 0 & 0 & 0 & - \\
\hline Monoplacophora & 3 & 0 & 0 & 0 & - \\
\hline Marine Pulmonata & 32 & 6 & 19 & 1 & 17 \\
\hline Total & 2803 & 323 & 12 & 135 & 42 \\
\hline
\end{tabular}

* Includes all species in Panamic and Galapagos

$\dagger$ Includes both widespread and endemic species

$\ddagger$ Column 2 divided by column $1 \times 100$

$\S$ Occur only in Galapagos Islands

Tा Column 4 divided by column $2 \times 100$

\section{ALTERNATIVE EVOLUTIONARY SCENARIOS}

There is an apparent paradox between the two a priori biogeographic or evolutionary scenarios that, stated implicitly or explicitly, have occasionally appeared in the literature on marine invertebrate organisms in the Galapagos. The first scenario assumes that, because the islands are isolated in a cold water regime where currents are of temporal uncertainty, the marine invertebrate fauna has undergone adaptive radiation and speciation to a comparable degree as the well-known terrestrial biota. As a result of this line of reasoning, some taxonomists have accentuated morphological differences rather than similarities between species. Although difficult to pinpoint, this perspective seems to exist occasionally in the taxonomic literature as an unspoken assumption. One would be implying near heresy, in an evolutionary sense, to conclude that evolution of the marine biota has not been as spectacular as the evolution of the terrestrial biota. A recent example of this attitude has been clearly stated by Bratcher \& Burch (1971: 537) in a paper on the taxonomy of marine neogastropods: "Since Charles Darwin's day, the Galapagos Islands have fascinated naturalists as being the 'cradle of new species' for both vertebrate and invertebrate fauna, so it is not surprising that some of the Terebra species should prove to be new". Mayr (1978) described similar roadblocks against the advancement of evolutionary thinking as "silent assumptions, never fully articulated". Given the available modern evidence, I think it is time to re-evaluate some of the taxonomic interpretations of invertebrate organisms in the Galapagos.

The second a priori scenario considers some of the same evidence as in the first scenario but arrives at a different conclusion. This alternative view considers ocean currents in the eastern Pacific as dispersal routes to the islands for 
planktonic larvae. This would result in greater faunistic similarity to mainland populations and hence high taxonomic diversity when compared to island size.

The conflicting notions of isolation, dispersal, and rate of evolutionary change (or species longevity, see below) are difficult to reconcile. Stanley (1979: 170) suggested that radiation of shallow-water marine invertebrates around island archipelagos may be more common than generally thought. However, two of the properties of these animals, namely, high dispersal ability and low rate of speciation (Stanley, 1979: 260-265 and 229-260, respectively) suggest otherwise.

Latitudinal environmental gradients may exist for marine organisms in the Galapagos owing to differences in water-mass characteristics brought by currents differentially affecting the northern or southern islands in the archipelago (Abbott, 1966). These gradients can be greater than climatic differences on land. For marine invertebrates, the pattern of population distribution may be quite complex due to ocean current patterns within the islands themselves. Further studies of single species are needed to determine patterns of geographic variation between islands for comparison to differences with mainland populations.

\section{PALAEONTOLOGICAL CONSIDERATIONS}

\section{Previous investigations}

Accounts of the occurrence of fossil-bearing deposits in the Galapagos extend back to observations made by Charles Darwin in 1835. He noted the presence of molluscan shells on Chatham Island (San Cristobal) "embedded several hundred feet above the sea, in the tuff of two craters, distant from each other" (Darwin, 1891: 130). It is not known if Darwin collected specimens from these tuff cones, and I found no material in the British Museum (Natural History) amongst the invertebrate fossils collected by Darwin during the Beagle voyage. Although not observed directly, the mechanism of fossilization for beds observed by Darwin on San Cristobal is likely to be similar to that described from Cerro Gallena and Cerro Colorado on Santa Cruz Island by the 1982 expedition (MS in prep.), and is considered to be a widespread phenomenon in the Galapagos. Observations by the 1982 expedition with a discussion of the mechanism of formation of this little-known and poorly-understood mode of fossilization will be presented at a later date (MS in prep.). Berthiaume (1938) and Durham (1942) have described other examples of Cenozoic marine fossils preserved in volcanic tuffs. Wolf (1895) described "sparse shell remains" in palagonite tuff $100 \mathrm{~m}$ above sea level in the Galapagos but did not discuss the exact location of these deposits.

Dall \& Ochsner (1928) presented the first extensive treatment of Cenozoic fossils from the Galapagos. In addition to describing fossil localities from three islands and commenting on the likely geologic ages of the deposits, they described 39 new molluscan species that were then considered endemic, extinct species. Many of these species have since been shown to be synonyms of Recent Panamic species (Keen, 1971). The perspective of Dall \& Ochsner (1928) seems to have been one of emphasizing taxonomic and morphological differences rather than similarities. Additional references to Galapagos fossils were made by Dall (1924). However, in contrast to their taxonomic opinions, Dall \& Ochsner 
(1928) correctly considered the marine molluscan affinities of the Galapagos to be with the Panamic faunal province, an opinion shared by Hertlein \& Strong (1939) in their in-depth treatment of fossils from the islands. Hertlein \& Strong (1939) also commented on the occasional affinity between Galapagos species and the Caribbean and Indo-Pacific faunas. Hertlein (1972) documented the presence of 30 bivalve and 77 gastropod species from fossil deposits on Isla Baltra. Emerson (1967, 1978), and Zinsmeister \& Emerson (1979) have reviewed occurrences of Recent molluscs with Indo-Pacific affinities in the Galapagos. Sufficient quantities of information (such as that presented in the recent studies cited above) are just becoming available to allow important biogeographic conclusions to be drawn. These can be made by comparing the temporal composition of the molluscan fauna through analysis of both living and fossil species occurrences.

\section{Previous age assignments}

Dall \& Ochsner (1928) attribute fossil deposits at Vilamil (Isla Isabela), Isla Baltra, and Cerro Colorado (Isla Santa Cruz) to Tertiary and Pleistocene ages without being specific about age-determination criteria. Based on unspecified fossil evidence, the beach deposit at Vilamil is determined to be younger than either of the deposits found at Cerro Colorado and Baltra. Hertlein \& Strong (1939) assign Late Pleistocene or subfossil ages of deposits from James Bay (Isla San Salvador), Isla Baltra, Tagus Cove (Isla Isabela), and Isla Rabida. Hertlein (1972) re-evaluated the age of fossil deposits on Isla Baltra (previously considered Late Pleistocene by Hertlein \& Strong, 1939) and assigned a Pliocene age to the deposits. However, he did not attempt a more specific refinement to Upper, Middle, or Lower Pliocene. Durham (1965a, b), and Durham \& McBirney (1975) assigned the oldest age to any fossil deposit in the Galapagos by considering fragmental blocks of fossiliferous marine limestone from near Cerro Colorado (Isla Santa Cruz) to be Late Miocene. Unfortunately, specific age determination criteria were not reported by Dall \& Ochsner (1928), Hertlein \& Strong (1939), Durham (1965a, 1965b), Hertlein (1972), or Durham \& McBirney (1975). However, Durham (1979) stated that his late Miocene age-determination was based on "a large pecten that is difficult to differentiate from Lyropecten crassicardo (Conrad, 1857) of the California upper Miocene".

\section{RESULTS OF THE 1982 EXPEDITION}

Results of the 1982 expedition have been summarized briefly by Lipps \& Hickman (1982), and Pitt \& James (1983). Pitt (in press) has presented a brief narrative description of the 1982 expedition. A summary and a brief elaboration of results to date are presented below. Results of the 1982 expedition are used here to show how fossil evidence bears on the question of evolutionary rates and patterns among Galapagos organisms.

\section{Types of deposits}

Lipps \& Hickman (1982) have described and classified six types of marine deposits bearing remains of organisms. These deposits include: (1) tuff cones 
with marine fossils; (2) limestone and sandstone interbedded with basalt flows; (3) terrace deposits above sea level; (4) beach rock; (5) supratidal talus debris, and (6) recently uplifted ( $3 \mathrm{~m}$ in 1954 (Richards, 1957)) tidal and subtidal rocks and sand.

\section{Revised age assignments}

Previous workers have reported that the ages of these deposits (with the exception of (6) above, Urvina Bay) were Miocene, Pliocene and/or Pleistocene. Lipps \& Hickman (1982) stated that these ages cannot be reconciled with presently-available geologic evidence (such as Cox, 1983 and Simkin, in press). Taxonomic work in progress in Pitt \& James (1983) has shown that the majority of fossils are represented by living species. All fossil specimens found embedded in tuff cones at Cerro Gallena and Cerro Colorado on Isla Santa Cruz are assignable to recent species known to be living in the near-shore waters of the Galapagos or elsewhere in the Panamic faunal province (MS in prep.). This is a conservative estimation of the taxonomic affinities of these marine invertebrate fossils, because many of the standard taxonomic characters, such as shell colour pattern and internal soft anatomy (e.g. radular morphology), are not preserved. Lipps \& Hickman (1982) suggested that the tuff cones, interbedded sedimentary rocks, and terrace deposits on most islands are no older than about two million years, and that beach rock and talus deposits are at most a few hundred years old. They relied mainly on the information in Cox (1983) for age-determination criteria (J. H. Lipps and C. S. Hickman, pers. comm. 1982). These interpretations are compatible with plate tectonic and volcanologic interpretations of the young age of the Galapagos Islands (Cox, 1983; Simkin, in press; see also Pitt, in press, fig. 2).

\section{Stratigraphic correlation}

The dynamic processes of volcanic island formation and incorporation of sedimentary fossil deposits appear to have been quite variable throughout the island chain. Each deposit in the six-part classification scheme of Lipps \& Hickman (1982) can alternatively be considered unique temporally, lithologically, and palaeontologically (C.S. Hickman, pers. comm., 27 March 1982). This would reduce the likelihood of ever successfully making an archipelago-wide stratigraphic correlation without the aid of additional evidence, such as isotopic dates or biostratigraphy. Work in progress (by JHL) on the foraminifera of several deposits will hopefully clarify and contribute to our understanding of the age, environmental, and stratigraphic relationships of the deposits.

\section{Biogeographic affinities}

Basic taxonomic decisions ultimately determine the biogeographic (and evolutionary) affinities of a fauna. To date, most fossil specimens collected by the 1982 expedition have been assigned to taxa with living representatives in the Panamic molluscan faunal province. However, one fossil from Isla Baltra appears to be a representative of the Indo-Pacific molluscan faunal province, a 
specimen tentatively assigned to an Indo-Pacific species of the widespread archeogastropod genus Nerita (W. D. Pitt, pers. comm., 7 April 1983). This represents the first known example of a fossil representative of the vagrant species component of the Galapagos (Emerson, 1967, 1978). Fallaw (1983) has recently shown that narrowing of the Pacific Ocean basin during Mesozoic and Cenozoic time aided migration of marine invertebrates between the Americas and the Indopacific-Asian landmasses.

Having presented background information on the Galapagos and a discussion of the results of the 1982 expedition, some of the differences between terrestrial and marine organisms are considered below. These serve to illustrate why different evolutionary scenarios might apply to the two groups.

\section{TERRESTRIAL-MARINE COMPARISONS}

Biological contrasts between the land and sea biotas of the Galapagos have generally not been made. However, this is unfortunate because some interesting differences emerge suggesting important evolutionary implications.

\section{Endemism and higher taxa}

A review of the taxonomic literature of the Galapagos provides two observations concerning endemism and the incidence of higher taxa. These suggest different evolutionary scenarios for terrestrial and marine organisms. Firstly, endemism is observed to be lower in the marine invertebrate fauna than in the terrestrial biota (Hedgpeth, 1969). Secondly, very few endemic marine invertebrate higher taxa have been described from the islands. Kay (1979: 15) noted a similar situation with respect to endemicity at higher taxonomic levels for marine molluscs in the Hawaiian Islands. Thus, when evolutionary divergence has occurred it has been manifested mainly at the species level. Recognition of higher taxa is a subjective process dependent on the opinions of individual taxonomists specializing in particular groups. As a consequence, some taxonomic groups will have higher taxonomic levels (usually genera) described as endemic from the Galapagos while others will not. Stanley (1979: 138) provided one of the few coherent generic concepts I have read. He stated that a typical genus forms by one or a small number of markedly divergent speciation steps (emphasis mine). By highlighting not only the number of speciation events but also a high degree of divergence per speciation, Stanley has emphasized both the quantity and magnitude of evolutionary change required to provide a new genus. Separating out biological reality from taxonomic artifact is of supreme importance when trying to understand the evolutionary history of organisms in the Galapagos.

\section{Dispersal stage and mechanism}

One important attribute of marine invertebrate reproductive biology, in contrast to that of terrestrial organisms, lies in the fact that many groups, including some molluscs, exchange genetic material via planktonic larvae (Thorson, 1950). Terrestrial vertebrates possess no such readily-dispersed stage (Matthew, 1930). Furthermore, the mechanism of transport for marine 
invertebrates is largely through drifting in ocean currents in contrast to being blown by the wind (e.g. birds, plants), rafting (e.g. plants, reptiles), or attachment to birds (e.g. plants) for terrestrial organisms (see Carlquist, 1974: 45 96). MacArthur \& Wilson (1967: 157-159) have pointed out that the common loss of dispersal abilities in many terrestrial island organisms (such as birds, insects, and plants) is directly attributable to alteration of dispersal mechanisms via "various combinations of several morphological changes". A fundamental difference exists in the biological stage of development at which dispersal occurs in marine invertebrates and terrestrial vertebrates. In the former, dispersal occurs at the larval stage very early in the life history of the organism, and in the latter, dispersal is by way of gravid females (or more than one individual of separate sexes). The establishment of the fact of larval dispersal in marine molluscs has been thoroughly reviewed by Lutz \& Jablonski (1980). Plant dispersal in and between islands usually involves both a specialized seed adaptation and a bird vector (see Carlquist, 1974: 45-96).

\section{Probability of dispersal}

Given the differences in dispersal stage and mechanism in marine invertebrate and terrestrial organisms, dispersal of terrestrial organisms is likely to be an accidental event of low probability (with the possible exception of plants), whereas in marine organisms dispersal is a life history event of higher (almost mandatory) probability. The probability of dispersal for an organism has important evolutionary consequences (see Stanley, 1979: Ch. 9), and hence, the differences between marine invertebrate and terrestrial organisms are of great value.

Dispersal and the founder principle (Mayr, 1942) have been critically examined by Rotondo, Springer, Scott \& Schlanger (1981) in relation to the establishment of endemic biotas. Island integration (Rotondo, et al., 1981) is suggested as a possible alternative mechanism in the formation of Hawaiian Islands endemism. Application of this concept to the Galapagos Islands is uncertain because the Galapagos are not a linear island chain (Byerly, 1980).

\section{Degree of isolation}

The higher probability of genetic contact with mainland source populations through planktonic larvae means that marine invertebrates experience a lower degree of isolation than the majority of terrestrial organisms. Isolation of the island group by sheer distance from the mainland has been important evolutionarily and now has major biogeographic consequences for the terrestrial biota. However, this pattern is not observed to the same degree in the marine biota due to the dispersal of planktonic larvae by ocean currents.

\section{Taxonomic hierarchy}

Consideration of the evolutionary relationships of the Galapagos biota usually involves several taxonomic comparisons, which can be ranked in a hierarchical fashion. Firstly, when investigating ancestor-descendant relationships for a particular lineage, taxonomists usually compare island species with South American mainland or Caribbean species. At this level the greatest taxonomic 
or morphological differences are seen. It is standard for comparisons of this sort to be made for both marine invertebrate and terrestrial organisms. Secondly, inter-island populations of a species can be compared and, in these cases, smaller morphological differences are usually observed. These comparisons, although quite common in terrestrial vertebrates and plants, are almost absent in marine invertebrates. I know of no inter-island population differences in marine invertebrates that are comparable to those of terrestrial organisms in the Galapagos. A multivariate study of one gastropod species (Conus nux) throughout the eastern Pacific did not reveal any taxonomically significant morphological differences between five populations in the Galapagos and 18 other populations located between the Galapagos and the Gulf of California (James, 1982). Lastly, intra-island taxonomic comparisons reveal even more subtle morphological differences (usually at the subspecies or race level) but have only been noted in terrestrial organisms. This hierarchy of taxonomic differences (mainland to archipelago, inter-island, and intra-island) is what makes the terrestrial biota of the Galapagos of such great evolutionary interest. These differences are not significant for marine invertebrates. However, valid taxonomic comparisons can be made between mainland populations (or otherwise in the Panamic province) and island populations of endemic species. Endemism at higher taxonomic levels is conspicuously absent from the fauna. Thus, the hierarchy of taxonomic differences as seen in terrestrial organisms is not seen in marine invertebrate organisms.

\section{Island definitions}

The taxonomic hierarchy described above assumes island populations are clear-cut and can be easily compared with other island or mainland populations elsewhere. A problem concerning the study of marine organisms associated with islands involves the bathymetric definition of what is actually in the Galapagos (Shumway \& Chase, 1963). Many marine species (particularly molluscs) have been described from very deep water adjacent to the islands and are standardly considered part of the marine biota (e.g., Keen, 1971). The subject of deeper water marine faunas associated with the Galapagos Islands has recently been considered by Valentine (as discussed above). However, to date, this fauna remains unstudied and consequently unpublished. Until it can be examined more thoroughly it is best not considered further in this discussion. For comparative purposes, restricting (by definition) the marine fauna to those species occurring in relatively shallow water may be necessary. In this way inter-island populations can be more readily compared for morphological and evolutionary differences. This situation is in contrast to the terrestrial biota where problems of defining the geographic limits of particular islands are not difficult. For the terrestrial biota, island populations are clear-cut: i.e., an island is defined by its coastline. Marine birds and fish form an exception to this rule, however.

\section{Intrinsic rate of evolutionary change}

The rate at which organisms diverge evolutionarily will have an impact on the degree of differentiation among taxa in an area such as the Galapagos. The data 
presented by Stanley $(1978,1979)$ for bivalved molluscs and mammals, although still highly controversial, indicate that these groups of organisms undergo differential rates of evolutionary change. If this is true for invertebrate and vertebrate organisms in general, then another line of reasoning can be added to the processes accounting for different patterns of evolutionary change among the two groups. Lower rates of intrinsic evolutionary change will probably result in a reduced amount of external morphological change through time. External morphology is the basis of most taxonomic decisions in fossil and living molluscs (and other shelled invertebrates). The lack of morphological change through time is the raw data (translated into taxonomic similarity) for suggesting a different evolutionary scenario among marine invertebrate organisms.

\section{Age of fossils}

In addition to the taxonomic hierarchy based on present-day geographic differences among taxa, another valuable comparison, divulging information on rates of evolutionary change lies in the temporal aspect of comparing fossil remains with living organisms in the Galapagos. In this regard, marine invertebrate fossils from the islands are older than the known vertebrate fossil record (Steadman, 1982; Steadman \& Ray, 1982; Lipps \& Hickman, 1982; Pitt \& James, 1983). These older marine invertebrate fossils provide a more complete temporal picture from which we may infer evolution in the islands than can be obtained for terrestrial organisms. Comparisons (taxonomic or morphologic) of present-day island populations run the risk of using incorrect character choices as the basis for establishing biogeographic or evolutionary relationships. Fossil evidence will more clearly indicate ancestor-descendant relationships. In this respect the palynological record provides valuable information about plant species occurrences in the past as well as climatic changes (Colinvaux, 1969, 1972).

\section{Taxonomic relationships}

Because marine invertebrate organisms have not diverged as far (morphologically) from mainland source populations as have many of the Galapagos terrestrial organisms, the taxonomic (and thus phylogenetic) relationships of living and fossil species are not as blurred as in, for example, Darwin's Finches (Steadman, 1982). In contrast, however, very little work has been carried out investigating the evolutionary relationships of marine invertebrate organisms, beyond the purely descriptive level. Biochemical studies on the giant tortoises Geochelone elephantopus (Marlow \& Patton, 1981), Galapagos finches (Geospizinae) (Yang \& Patton, 1981), and introduced rodent populations of Rattus rattus (Patton, Yang \& Myers, 1975) have provided information on the taxonomic and phylogenetic relationships of terrestrial organisms. This provides a complement to purely morphological studies. Unfortunately, taxonomic decisions can be biased by the reputation of the spectacular terrestrial biota of the Galapagos. Additional work is needed beyond the level of alpha taxonomy for marine invertebrate organisms in the Galapagos to determine more precisely their evolutionary relationships. 


\section{PATTERN AND PROCESS REVISITED}

Different patterns are seen in the evolution of marine and terrestrial organisms in the Galapagos. In terms of Darwin's evolutionary scenario, terrestrial organisms represent the paradigm and marine organisms represent the paradox. Fortunately, there are two processes that account for these patterns. Firstly, as mentioned above, many marine organisms have the ability to exchange genetic material between island and mainland populations through planktotrophic (or merely planktonic, sensu Lutz \& Jablonski, 1980) larvae. Terrestrial organisms do not have this ability. Secondly, molluscs undergo intrinsically slower rates of evolutionary change than mammals (Stanley, 1979: 101-142). If this is a general indication of the difference between vertebrates and invertebrates, then it is not surprising that, when combined with the ability to exchange genetic material mentioned above, marine invertebrate organisms in the Galapagos do not exhibit a large degree of evolutionary divergence from mainland source populations. The differential rate of evolutionary divergence then comprises this 'new look at evolution in the Galapagos Islands'.

\section{CONCLUSIONS}

Evolution of the marine invertebrate biota of the Galapagos Islands, (as evidenced both by the living species, and by recent studies of fossil-bearing deposits) has proceeded at a much slower rate than the evolution of the terrestrial biota. The geologically young age of the islands suggests that terrestrial evolution, producing the spectacular terrestrial biota, has occurred comparatively quickly. The evolutionary scenario for terrestrial organisms is usually one of dispersal followed by adaptive radiation and speciation into unoccupied niche space. All of this is a consequence of the low probability of further influxes of genetic material from mainland source populations, thus maintaining a restricted gene pool. This scenario does not, however, generally hold for marine invertebrate organisms where rates of dispersal and genetic exchange are much higher. Consideration of this alternative evolutionary scenario should be useful when making taxonomic decisions relating to the marine invertebrate fauna of the Galapagos Islands.

\section{ACKNOWLEDGEMENTS}

For aiding the 1982 expedition I thank Dr Friedemann Koster for making available the services and facilities of the Charles Darwin Research Station (CDRS); the Galapagos National Park Service for expediting our field work; Dr David Duffy, former Director CDRS, for extending to one of us (WDP) an invitation to investigate the marine paleontology of the islands; the Navy and Air Force of Ecuador for access to fossil localities on Isla Baltra; and the De Roy family (Jaqueline, Andre, and Gil) for valuable locality information. Sincere thanks are extended to Mr Patrick F. Fields for providing thorough reviews of multiple drafts of the manuscript and for making numerous valuable suggestions that greatly improved its content. Ms Cynthia S. Leung copyedited the manuscript. Figures were prepared by Mary Taylor (UCMP). I appreciate the courtesy extended by Professor R. J. Berry for inviting the submission of this 
paper. Critical reviews of the manuscript were kindly provided by Drs J. Wyatt Durham and David R. Lindberg resulting in the clarification of several points. However, neither necessarily agreed with all aspects of this paper, and consequently, the author bears full responsibility for everything discussed herein.

\section{REFERENCES}

ABBOTT, D. P., 1966. Factors influencing the zoogeographic affinities of Galapagos inshore marine fauna. In R. I. Bowman (Ed.), The Galapagos: Proceedings of the Symposia of the Galapagos International Scientific Project: 108-122. Berkeley: University of California Press.

BERRY, R. J., 1979. The Outer Hebrides: where genes and geography meet. Proceedings of the Royal Society of Edinburgh, $77 B: 21-43$.

BERTHIAUME, S. A., 1938. Orbitoids from the Cresent Formation (Eocene) of Washington. Journal of Paleontology, 12(5): $494-497$

BRATCHER, T. \& BURCH, R, D., 1971. The Terebridae (Gastropoda) of Clarion, Socorro, Cocos, and Galapagos Islands. Proceedings of the California Academy of Sciences Fourth Series Vol. 37, No. 21: 537-566.

BRIGGS, J. C., 1966. Oceanic islands, endemism, and marine paleotemperatures. Systematic Zoology 15(2): $153-163$

BYERLY, G., 1980. The nature of differentiation trends in some volcanic rocks from the Galapagos Spreading Center, Journal of Geophysical Research, 85(B7): 3797-3810.

CAR LQUIST, S. J., 1974. Island Biology. New York: Columbia University Press. 660 pp.

COLINVAUX, P. A., 1969. Vegetation of a Galapagos island before and after an ice age. Annals of the Missouri Botanical Garden, $56(3): 419$.

COLINVAUX, P. A., 1972. Climate and the Galapagos Islands. Nature, 240: 17-20.

COX, A. 1983. Age of the Galapagos Islands. In R. I. Bowman, M. Berson \& A. E. Leviton (Eds), Patterns of Evolution in Galapagos Organisms: 11-23. San Francisco: American Association for the Advancement of Science, Pacific Division.

DALL, W. H., 1924. Note on fossiliferous strata of the Galapagos Islands explored by W. H. Ochsner of the Expedition of the California Academy of Sciences in 1905-6. Geological Magazine, 61(723): 428-429.

DALL, W. H. \& OCHSNER, W. H., 1928. Tertiary and Pleistocene Mollusca from the Galapagos Islands. Proceedings of the California Academy of Sciences, Fourth Series Vol. 17, No. 4: 89-138.

DARWIN, C. R., 1891. Geological Observations on the Volcanic Islands and parts of South America visited during the Voyage of H.M.S. 'Beagle' (3rd edition), London: Smith, Elder, \& Co., xiii +648 pp.

DRUFFEL, E. M., 1981. Radiocarbon in annual coral rings from the eastern tropical Pacific Ocean. Geophysical Research Letters, 8(1): 59-62.

DURHAM, J. W., 1942. Eocene and Oligocene coral faunas of Washington. Journal of Paleontology, 16(1): 84-104.

DURHAM, J. W., 1965a. Geology of the Galapagos Islands. Pacific Discovery, 18(5): 3-6.

DURHAM, J. W., 1965b. The Galapagos Islands Expedition of 1964. Annual Reports for 1964 of the American Malacological Union: 53.

DURHAM, J. W., 1979. A fossil Haliotis from the Galapagos Islands. The Veliger, 21(3): 369-372.

DURHAM, J. W., 1980. A new fossil Pocillopora (Coral) from Guadalupe Island, Mexico. In D. M. Power (Ed.), The California Islands: Proceedings of a Multidisciplinary Symposium: 63-70. Santa Barbara, California: Santa Barbara Museum of Natural History.

DURHAM, J. W. \& McBIRNEY, A. R., 1975. Galapagos Islands. In: R. W. Fairbridge (Ed.), The Encyclopedia of World Regional Geology, Part 1: 285-290. Stroudsburg: Dowden, Hutchison and Ross, Inc.

EDWARDS, A. \& LUBBOCK, R., 1983. Marine zoogeography of St. Paul's Rocks. Journal of Biogeography lO(1): $65-72$.

EKMAN, S., 1953. Zoogeography of the Sea. London: Sidgwick and Jackson, Ltd. xiv $+417 \mathrm{pp}$.

EMERSON, W. K., 1967. Indo-Pacific faunal elements in the tropical eastern Pacific, with special reference to the mollusks. Venus, 25(3-4): 85-93.

EMERSON, W. K., 1978. Mollusks with Indo-Pacific faunal affinities in the eastern Pacific Ocean. The Nautilus, 92(2): 91-96.

FALLAW, W. C., 1983. Trans-Pacific faunal similarities among Mesozoic and Cenozoic invertebrates related to plate tectonic processes. American Journal of Science, 283: 166-172.

FERREIA, A. J., 1978. A new species of chiton (Neoloricata: Ischnochitonidae) from the Galapagos Islands. Bulletin of the Southern California Academy of Sciences 77(1): 36-39.

GARTH, J. S., 1946. Distributional studies of Galapagos Brachyura. Allan Hancock Pacific Expeditions, 5: $603-648$.

GEISTER, J., 1977. Occurrence of Pocillopora in late Pleistocene Caribbean coral reefs. In: Second Symposium international sur les coraux et recifs coralliens fossiles, Paris, September 1975, B.R.G.M. (Paris) Memoires No. 89: $378-388$. 
GLYNN, P. W., WELLINGTON, G. M. \& BIRKELAND, C., 1979. Coral reef growth in the Galapagos: Limitation by sea urchins. Science, 203: 47-49.

HALL, M. L., RAMON, P. \& YEPES, H., 1980. The subaerial origin of Espanola (Hood) Island and the age of terrestrial life in the Galapagos. Noticias de Galapagos, 31: 21.

HEDGPETH, J. W., 1969. An intertidal reconnaissance of rocky shores of the Galapagos. Wasmann Journal of Biology, 27: 1-24.

HERTLEIN, L. G. \& STRONG, A. M., 1939. Marine Pleistocene mollusks from the Galapagos Islands. Proceedings of the California Academy of Sciences, Fourth Series Vol. 23, No. 24: 367-380.

HERTLEIN, L. G., 1972. Pliocene fossils from Baltra (South Seymour) Island, Galapagos Islands. Proceedings of the California Academy of Sciences, Fourth Series Volume 34, No. 3: 25-46.

HICKMAN, C. S., 1976. Bathyal gastropods of the family Turridae in the Early Oligocene Keasey Formation in Oregon, with a review of some deep-water genera in the Paleocene of the eastern Pacific. Bulletins of American Paleontology, 70 (292): 1-119.

JABLONSKI, D. \& LUTZ, R. A., 1983. Larval ecology of marine benthic invertebrates: paleobiological implications. Biological Reviews, 58(1): 21-90.

JAMES, M. J., 1982. Analysis of morphometric variation in Conus nux: Biogeographic patterns in the eastern Pacific. Western Society of Malacologists, Annual Report 14: 12-13.

KAY, E. A., 1979. Hawaiian Marine Shells. Reef and Shore Fauna of Hawaii, Section 4: Mollusca, Bernice P. Bishop Museum Special Publication 64(4): xviii +653 pp.

KEEN, A. M., 1971. Sea Shells of Tropical West America (2nd edition), Palo Alto: Stanford University Press, xiv +1064 pp.

KEIGWIN, L. D., JR., 1978. Pliocene closing of the Isthmus of Panama, based on biostratigraphic evidence from nearby Pacific Ocean and Caribbean Sea cores. Geology, 6: 630-634.

LINDBERG, D. R. \& MCLEAN, J. H., 1981. Tropical eastern Pacific limpets of the family Acmaeidae (Mollusca, Archeogastropoda): Generic criteria and descriptions of six new species from the mainland and the Galapagos Islands. Proceedings of the California Academy of Sciences Vol. 42, No. 12: 323-339.

LINDBERG, D. R., ROTH, B., KELLOGG, M. G. \& HUBBS, G. L., 1980. Invertebrate megafossils of Pleistocene (Sangamon Interglacial) age from Isla Guadalupe, Baja California, Mexico. In D. M. Power (Ed.), The California Islands: Proceedings of a Multidisciplinary Symposium: 41-62. Santa Barbara, California: Santa Barbara Museum of Natural History.

LIPPS, J. H. \& HICKMAN, C. S., 1982. Paleontology and geologic history of the Galapagos Islands. GSA Abstracts with Programs 14(7): 548.

LUTZ, R. A. \& JABLONSKI, D., 1980. Molluscan larval shell morphology: Ecological and paleontological applications. In D. C. Rhoads \& R. A. Lutz (Eds), Skeletal Growth of Aqualtic Organisms: Biological Records of Environment Change: 323-377. New York: Plenum Press.

MACARTHUR, R. H. \& WILSON, E. O., 1967. The Theory of Island Biogeography. Princeton: Princeton University Press. 203 pp.

MARINCOVICH, L. N., JR., 1973. Intertidal mollusks of Iquique, Chile. Los Angeles County Natural History Museum Science Bulletin 16: 1-49.

MARLOW, R. W. \& PATTON, J. L., 1981. Biochemical relationships of the Galapagos Giant tortoises (Geochelone elephantopus). Journal of Zoology, London 195: 413-422.

MATTHEW, W. D., 1930. The dispersal of land animals. Scientia, July: 33-42.

MAYR, E., 1942. Systematics and the Origin of Species. New York: Columbia University Press. 334 pp.

MAYR, E., 1978. The nature of the Darwinian revolution. In S. L. Washburn \& E. R. McCown (Eds), Human Evolution: Biosocial Perspectives: 11-31. Menlo Park: Benjamin/Cummings Publishing Co.

PATTON, J.L., YANG, S.Y. \& MYERS, P., 1975. Genetic and morphologic divergences among introduced rat populations (Rattus rattus) of the Galapagos Archipelago, Ecuador. Systematic Zoology, 24 (3): 296-310.

PITT, W. D. (in press). Late Cenozoic marine paleontology of the Galapagos Islands. Annual Report of the Charles Darwin Research Station.

PITT, W. D. \& JAMES, M. J., 1983. Late Cenozoic marine invertebrate paleontology of the Galapagos Islands. Western Society of Malocologists, Annual Report, 15: 14-15.

RICHARDS, A. F., 1957. Volcanism in eastern Pacific Ocean basin: 1945-1955. In: International Geological Congress 20th Session, Mexico City, 1956. Section 1, Volcanology of the Cenozoic, Volume 1, pp. 19-31.

ROSEN, B. R., (in prep). The geological nature of the Galapagos Islands and implications for its shallow marine fauna and reef development.

ROTONDO, G. M., SPRINGER, V. G., SCOTT, G. A. J. \& SCHLANGER, S. O., 1981. Plate movement and island integration-A possible mechanism in the formation of endemic biotas, with special reference to the Hawaiian Islands. Systematic Zoology, 30(1): 12-21.

SHUMWAY, G. \& CHASE, T. E., 1963. Bathymetry in the Galapagos Islands. Occasional Papers of the California Academy of Sciences, 44: 11-19.

SIMKIN, T., (in press). Geology of Galapagos. In R. Perry (Ed.), Chapter 2 in Pergamon Press book on Galapagos (in new "Key Environments" series edited by John Treherne).

SMITH, A. G. \& FERREIA, A. J., 1977. Chiton fauna of the Galapagos Islands. The Veliger, 20 (2): $82-97$.

STANLEY, S. M., 1978. Chronospecies' longevities, the origin of genera, and the punctuational model of evolution. Paleobiology, 4: 26-40. 
STANLEY, S. M., 1979. Macroevolution, Pattern and Process. San Francisco: W. H. Freeman and Co. 332 pp.

STEADMAN, D. W. 1982. The origin of Darwin's finches (Fringillidae, Passeriformes). Transactions of the San Diego Society of Natural History, 19(19): 279-296.

STEADMAN, D. W. \& RAY, C. E., 1982. The relationships of Megaoryzomys curioi, an extinct Cricetine rodent (Muroidea: Muridae) from the Galapagos Islands, Ecuador. Smithsonian Contributions in Paleobiology No. $51,23 \mathrm{pp}$.

THORSON, G., 1950. Reproductive and larval ecology of marine bottom invertebrates. Biological Reviews, 25 : $1-45$.

VERMEIJ, G. J., 1978. Biogeography and Adaptation. Cambridge, Massachusetts: Harvard University Press. 332 pp.

WALKER, B. W. \& ROSENBLATT, R. H., 1961. The marine fishes of the Galapagos Islands. Abstracts of Symposium Papers, Tenth Pacific Science Congress, Honolulu, Hawaii: 470-471.

WELLINGTON, G. M., 1978. Undersea wonders of the Galapagos. National Geographic, 154(3): 362-381.

WILLIAMSON, M., 1981. Island Populations. Oxford: Oxford University Press. $286 \mathrm{pp}$.

WILLIAMSON, M., 1983. Variations in population density and extinction. Nature, 303: 201.

WOLF, T., 1895. Die Galpagos-Inseln. Verhandlungen der Gesellschaft fur Erdkunde zu Berlin, 22: 246-265.

WOOSTER, W. S. \& HEDGPETH, J. W., 1966. The oceanographic setting of the Galapagos. In R. I. Bowman (Ed.), The Galapagos: Proceedings of the Symposia of the Galapagos International Scientific Project: 100-107. Berkeley: University of California Press.

WYRTKI, K., STROUP, E., PATZERT, W., WILLIAMS, R. \& QUINN, W, 1976. Predicting and observing El Nino. Science 191: 343-346.

YANG, S. Y. \& PATTON, J. L., 1981. Genic variability and differentiation in the Galapagos finches. The Auk, 98: $230-242$.

ZINSMEISTER, W. J. \& EMERSON, W. K. 1979. The role of passive larval dispersal in the distribution of hemipelagic invertebrates, with examples from the tropical Pacific Ocean. The Veliger, 22(l): 32- 40. 